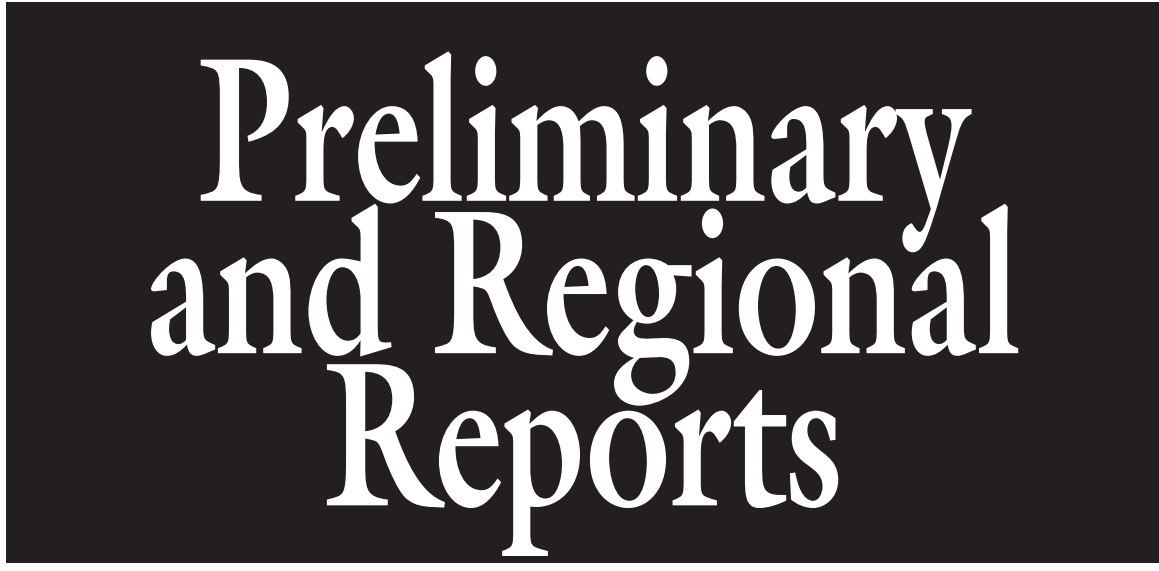

\title{
Aesthetic and Economic Impacts Associated with Four Different Cool-season Lawn Fertility and Pesticide Programs
}

\author{
Victoria A. Caceres ${ }^{1,3}$, Cale A. Bigelow ${ }^{2}$, and Douglas S. Richmond
}

ADDITIONAL INDEX WORDs. canopy greenness, consumer, integrated pest management, natural organic, no input, scouting, thresholds

Summary. Aesthetic and economic characteristics of different turfgrass fertility and pesticide programs were compared in an effort to provide a framework for lawn care professionals to evaluate, market, and implement alternative management strategies. Programs included a consumer program (CP), an integrated pest management program (IPMP), a natural organic program (NOP), and a no-input program (NIP). All programs significantly improved visual appearance compared with the NIP, and although the IPMP and CP consistently had the highest ratings, the NOP produced lawns of similar quality on the majority of rating dates. The NOP also resulted in canopy greenness levels similar to or significantly greater than those provided by the IPMP and CP on most dates. Aside from the NIP, the lowest total maintenance costs were associated with the IPMP during both study years.

Although the NOP was the most expensive program when white grub (Coleoptera: Scarabaeidae) populations exceeded treatment thresholds, it was less expensive than the CP when white grubs were below thresholds. Incorporation of scouting into different fertility and pesticide programs resulted in short-term economic benefits without significantly compromising turfgrass aesthetic quality.

$\mathrm{L}$ awns have aesthetic, functional, and monetary value, and represent an important part of most urban landscapes. Attractive landscaping conveys a favorable impression in a business setting and may increase the value of residential properties by as much as $15 \%$ (Mangiafico and Guillard, 2006). To

This work was supported by the College of Agriculture at Purdue University and by the Mid-west Regional Turf Foundation.

We thank A. Nance, T. Hoctor, E. O'Neil, and W. Baldauf for technical assistance.

${ }^{1}$ Department of Entomology, Purdue University, 901 West State Street, West Lafayette, IN 47907

${ }^{2}$ Department of Agronomy, Purdue University, 901 West State Street, West Lafayette, IN 47907

${ }^{3}$ Corresponding author. E-mail: vcaceres@purdue.edu. measure turfgrass quality, turfgrass scientists and other professionals usually employ a set of subjective measures aimed at capturing a broad set of visual and/or functional turfgrass characteristics (Turgeon, 2002). The six basic components of turfgrass quality are uniformity, density, texture, growth habit, smoothness, and color (Beard, 1973). For home lawns, color and uniformity are most important (Beard, 1973). Regardless of the species, the public generally associates a high-quality lawn as one possessing a consistent dark-green color and high shoot density, and this is a major consideration when suggesting fertilization programs for lawns (Walker et al., 2007). Therefore, any attempt by lawn care professionals to integrate and market alternative turfgrass management philosophies must be mindful of the considerable importance of aesthetic quality when determining whether alternative approaches can satisfy consumer demands.

Warranted or not, traditional turfgrass management programs, which tend to rely heavily on synthetic pesticide and fertilizer inputs, have been the focus of increased public scrutiny and legislative activity (Williamson, 2007). Pesticide inputs associated with turfgrass lawns may negatively impact the turfgrass ecosystem, contributing to declines in populations of beneficial soil organisms (Desneux et al., 2007; Rochefort, 2006) and thatch accumulation, leading to poor root systems and reduced plant vigor (Beard, 1973). Research indicates that lawn management programs can influence soil nutrient pools (Cheng et al., 2008b), and that excessive amounts of synthetic fertilizers can cause plant nutrient imbalances, potentially reducing plant resistance to insect pests and diseases (Altieri and Nicholls, 2003; Phelan et al., 1995). In contrast, organic fertilizers rely more heavily on soil organisms to gradually mineralize and release nutrients to the rhizosphere (Altieri and Nicholls, 2003; Bulluck and Ristaino, 2001),

\begin{tabular}{llll}
\hline $\begin{array}{l}\text { Units } \\
\begin{array}{l}\text { To convert U.S. to SI, } \\
\text { multiply by }\end{array}\end{array}$ & U.S. unit & SI unit & $\begin{array}{l}\text { To convert SI to U.S., } \\
\text { multiply by }\end{array}$ \\
\hline 0.4047 & acre $(\mathrm{s})$ & $\mathrm{ha}$ & $2.471 \mathrm{l}$ \\
73.0778 & $\mathrm{fl} \mathrm{oz} / \mathrm{acre}$ & $\mathrm{mL} \cdot \mathrm{ha}^{-1}$ & 0.0137 \\
0.3048 & $\mathrm{ft}$ & $\mathrm{m}$ & 3.2808 \\
0.0929 & $\mathrm{ft}^{2}$ & $\mathrm{~m}^{2}$ & 10.7639 \\
2.54 & inch $(\mathrm{es})$ & $\mathrm{cm}$ & 0.3937 \\
25.4 & inch $(\mathrm{es})$ & $\mathrm{mm}$ & 0.0394 \\
6.4516 & inch & $\mathrm{cm}^{2}$ & 0.1550 \\
48.8243 & lb $/ 1000 \mathrm{ft}^{2}$ & $\mathrm{~kg} \cdot \mathrm{ha}^{-1}$ & 0.0205 \\
1.1209 & lb/acre & $\mathrm{kg} \cdot \mathrm{ha}^{-1}$ & 0.8922 \\
1.6093 & mile $(\mathrm{s})$ & $\mathrm{km}$ & 0.6214 \\
$\left({ }^{\circ} \mathrm{F}-32\right) \div 1.8$ & ${ }^{\circ} \mathrm{F}$ & ${ }^{\circ} \mathrm{C}$ & $\left(1.8 \times{ }^{\circ} \mathrm{C}\right)+32$
\end{tabular}


potentially resulting in a more balanced nutrient solution and healthier plants (Altieri and Nicholls, 2003).

Although organic and biological alternatives to synthetic fertilizers and pesticides exist, they have not been widely adopted by homeowners or the lawn care industry. The reasons for this lack of adoption are many, but primarily revolve around a combination of high aesthetic standards (Potter and Braman, 1991) and a perceived lack of reliability or cost effectiveness associated with biologically based alternatives (Potter and Braman, 1991; U.S. Congress, Office of Technology Assessment, 1995). Furthermore, the reluctance of property owners to pay for or engage in scouting and monitoring activities means there is no economic incentive for lawn care professionals to employ decision-making processes that could be useful for determining the need for individual management inputs. Studies that examine the economic and aesthetic impacts associated with different management programs and assess the utility of scouting and decision-making processes may provide useful insight into the actual costs and benefits associated with alternative management approaches and may provide a framework for more widespread adoption.

The objective of this field study was to evaluate and compare the aesthetic and economic characteristics of four divergent turfgrass fertility and pesticide programs. Aesthetic characteristics were determined by measuring canopy greenness and visually rating turfgrass quality (color, density, and uniformity), whereas economic aspects were determined by recording the cost of materials and labor associated with each fertility and pesticide program.

\section{Materials and methods}

EXPERIMENTAL SITE. This field study was conducted in West Lafayette, IN, from June 2005 through Oct. 2006 using a mature set of simulated landscape plots established in 1999 for another study by Rebek et al. (2005). The soil type in the experimental site was Carmi loam with $0 \%$ to $2 \%$ slopes and soil $\mathrm{pH}$ between 6.8 and 7.1. Each plot measured $18 \times 6 \mathrm{~m}$ and consisted mainly of kentucky bluegrass [Poa pratensis $(80 \%)]$ mixed with perennial ryegrass [Lolium perenne (4\%)], tall fescue [Schedonorus arundinaceus (10\%)], and creeping red fescue [Festuca rubra (6\%)]. Each plot was managed using one of four different turfgrass fertility and pesticide programs, which were replicated five times, using plots arranged in a randomized complete block design.

Fertility and pesticide PROGRAMS. The fertility and pesticide programs implemented on the plots included the following: 1) a consumer program (CP) based on Scotts ${ }^{\circledR}$ (Marysville, $\mathrm{OH}$ ) annual five-step program composed of calendar-driven applications of preformulated fertilizers, insecticides, and herbicides. Products, application rates, and approximate dates were determined using Scotts Annual Program Builder. 2) An integrated pest management program (IPMP) that relied on sound cultural practices in conjunction with monitoring to determine if blanket herbicide and insecticide applications were necessary based on scouting results. When any weeds were present in the plots, liquid formulations of pre- and post-emergent synthetic herbicides were applied (Table 1) using a pressurized sprayer. To determine if white grub (Popillia japonica, Cyclocephala borealis, Cyclocephala lurida, and Phyllophaga spp.) populations exceeded treatment thresholds, five soil core samples (4.25 inches diameter $\times 3.0$ inches deep) were randomly taken from each plot and examined for white grubs. If three or more white grubs were found in the five 0.44 -inch ${ }^{2}$ soil core samples taken ( $\geq 6$ grubs $\left./ \mathrm{ft}^{2}\right)$, a liquid formulation of the insecticide imidacloprid (Merit 2F; Bayer, Research Triangle Park, NC) was applied using a handoperated carbon dioxide-pressurized boom sprayer. 3) A natural organic program (NOP), which relied on sound cultural practices and the use of biological alternatives with no use of synthetic fertilizers or pesticides. Weed management relied on applications of corn gluten meal for preemergent grassy weed control. Corn gluten meal also served as an organic fertilizer in these plots. White grub scouting in the NOP was exactly the same as for the IPMP. However, when white grub densities exceeded treatment threshold levels (6-10 grubs $\left./ \mathrm{ft}^{2}\right)$, entomopathogenic nematodes (Heterorhabditis bacteriophora-HP88 strain) were applied at a rate of 1 billion/acre. 4) A no-input program (NIP), which served as an experimental control. These plots received regular mowing and supplemented irrigation, but no other inputs.

All plots were mowed at 3.0 inches using a riding mower (Hustler, FasTrak $^{\mathrm{TM}}$ 44/52; Excel Industries, Hesston, KS), and mowing frequency was determined by turfgrass growth, but averaged about every 7 days from April through October. All plots were mowed at the same frequency. Plots were irrigated only to avoid turfgrass dormancy and to facilitate application of inputs. All programs, except for the $\mathrm{NIP}$, received $\approx 2.8$ and $3.3 \mathrm{lb} / 1000$ $\mathrm{ft}^{2}$ of nitrogen (N) during 2005 and 2006 , respectively. This amount of $\mathrm{N}$ fertility was determined based on fertilizer recommendations for the $\mathrm{CP}$, and was incorporated into the IPMP and NOP to keep N fertility inputs even across programs. However, total $\mathrm{N}$ amounts were split into three or four applications depending on the fertility and pesticide program (Table 2).

Data collection. Weather data were collected from the Indiana State Climate Office in West Lafayette, IN, located 6.1 miles northwest of the research plots. Turfgrass quality was rated biweekly from April through October during the 2006 season using two different techniques. Visual quality ratings consisted of a composite rating that accounted for color, uniformity, and density on a 0 to 10 scale, where $0=$ complete absence of living turf, but potentially high weed cover, 6 = minimally acceptable lawn turf with few weeds, and $10=$ optimum uniformity, density, and greenness with no weeds present (Walker et al., 2007). Visual quality ratings, based on whole plots, were negatively influenced by weed cover, and did not specifically correspond to the health or appearance of turfgrass plants, but rather the quality of the turfgrass stand.

Canopy greenness was also quantified using a hand-held reflection meter (FieldScout CM-1000; Spectrum Technologies, Plainfield, IL). Ten approximately equally spaced measurements were taken once every 2 weeks along a 22 -ft diagonal transect 
Preliminary and Regional Reports

Table 1. Cost of materials and labor associated with four different lawn fertility and pesticide programs over the course of 2 years (2005-06).

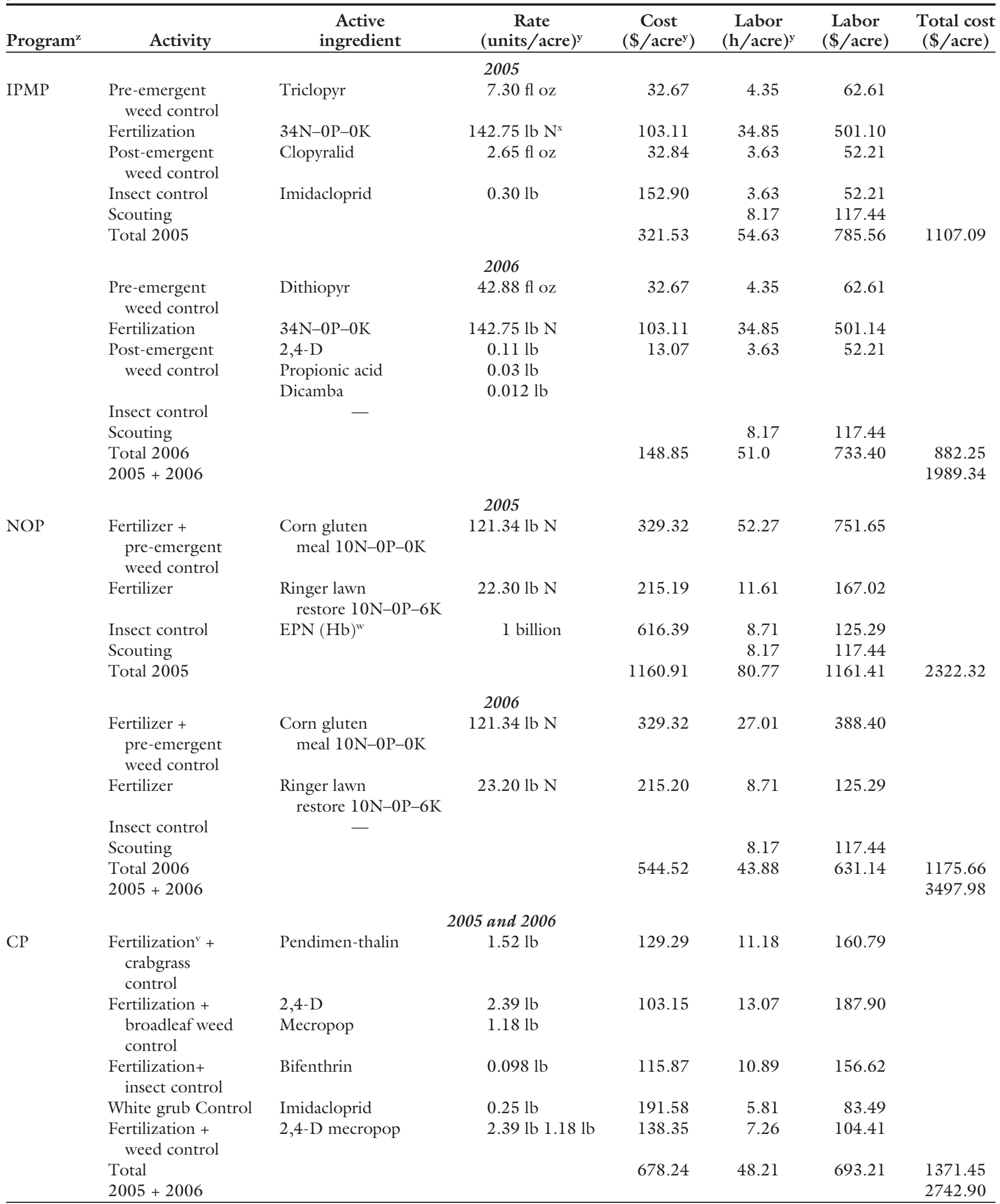

${ }^{\mathrm{z}} \mathrm{CP}=$ consumer program, IPMP $=$ integrated pest management program, $\mathrm{NOP}=$ natural organic program.

${ }^{\mathrm{y}} \mathrm{l} \mathrm{fl} \mathrm{oz} /$ acre $=73.0778 \mathrm{~mL} \cdot \mathrm{ha}^{-1}, \mathrm{l} \mathrm{lb} /$ acre $=1.1209 \mathrm{~kg} \cdot \mathrm{ha}^{-1}, \mathrm{l}$ billion $/$ acre $=2.471 \mathrm{l} \mathrm{billion} / \mathrm{ha}, \$ 1.00 /$ acre $=\$ 2.471 \mathrm{l} / \mathrm{ha}, \mathrm{l} \mathrm{h} / \mathrm{acre}=2.471 \mathrm{l} \mathrm{h} \cdot \mathrm{ha}{ }^{-1}$.

${ }^{x} \mathrm{~N}=$ nitrogen.

wEPN $(\mathrm{Hb})=$ entomopathogenic nematodes (Heterorhabditis bacteriophora).

vertilizer applied in CP was $28 \mathrm{~N}-1.3 \mathrm{P}-6.6 \mathrm{~K}$. 
Table 2. Monthly nitrogen $(\mathrm{N})$ inputs associated with four different lawn fertility and pesticide programs: consumer program (CP), integrated pest management program (IPMP), natural organic program (NOP), and no input program (NIP) implemented on simulated urban landscape plots during 2005 and 2006.

\begin{tabular}{|c|c|c|c|c|c|c|c|}
\hline $\begin{array}{l}\text { Fertility and } \\
\text { pesticide program }^{\mathrm{z}}\end{array}$ & April & May & June & July & August & September & $\begin{array}{c}\text { Annual } \\
\text { total }^{\mathrm{y}}\end{array}$ \\
\hline & \multicolumn{7}{|c|}{$2005 \mathrm{~N}$ input $\left(\mathrm{lb} / 1000 \mathrm{ft}^{2}\right)^{x}$} \\
\hline $\mathrm{CP}$ & & & 1.28 & & 0.72 & 0.86 & 2.86 \\
\hline IPMP & & & 1.36 & & 1.36 & & 2.72 \\
\hline NOP & & & 2.84 & & & & 2.84 \\
\hline \multicolumn{8}{|l|}{ NIP } \\
\hline & \multicolumn{7}{|c|}{$2006 \mathrm{~N}$ input (lb/1000 $\left.\mathrm{ft}^{2}\right)$} \\
\hline $\mathrm{CP}$ & 0.86 & 0.81 & & 0.78 & & 0.74 & 3.19 \\
\hline IPMP & & 1.36 & & 1.36 & & 0.58 & 3.30 \\
\hline NOP & 1.92 & & & 0.50 & & 0.88 & 3.30 \\
\hline NIP & & & & & & & \\
\hline
\end{tabular}

${ }^{\mathrm{z}} \mathrm{N}$ sources were as follows: ammonium nitrate $(34 \mathrm{~N}-0 \mathrm{P}-0 \mathrm{~K})$ for IPMP, corn gluten meal (10N-0P-0K) for NOP, and full analysis $(28 \mathrm{~N}-3 \mathrm{P}-8 \mathrm{~K}$ or $28 \mathrm{~N}-1.3 \mathrm{P}-6.7 \mathrm{~K})$ for $\mathrm{CP}$.

yAnnual total $\mathrm{N}$ for all programs was slightly lower in 2005 than in 2006 because 2005 was a shorter season with applications of inputs starting in late May, while applications of inputs in 2006 started in early April.

${ }^{x}$ All applications for a given month were made within a 1 -week time interval; $1 \mathrm{lb} / 1000 \mathrm{ft}^{2}=48.8243 \mathrm{~kg} \cdot \mathrm{ha}^{-1}$.

established across each plot. Weeds were intentionally avoided and the 10 measurements were averaged to produce a single measurement for each sampling date.

Because weed cover is an important factor when evaluating aesthetic quality, the composition of plant cover in the plots was quantified using the same diagonal transects established for canopy greenness measurements. The plants lying directly beneath each of 40 equally spaced points along each transect were identified to species and recorded twice in 2005 (28 July and 3 Oct.) and three times in 2006 (29 Apr., 5 July, and 6 Oct.). Data for each species was converted to percentage of cover by dividing the total number of times a species was encountered by 40 and multiplying by 100 .

To quantify economic parameters, material costs and labor were calculated and logged. Material costs included expenditures on fertilizers, herbicides, insecticides, and any other material applied to the plots. Labor included time spent scouting (IPMP and NOP) and making applications, and was estimated at a rate of $\$ 14.38$ per hour, a rate representing the mean hourly pay rate for lawn care technicians in north-central Indiana (\$10-\$18.75 per hour; B. Joyner, personal communication). Total program costs were calculated using the total area of the five plots included in each fertility and pesticide program $\left(\approx 5000 \mathrm{ft}^{2}\right)$, and were adjusted to estimate total costs on a dollars per acre basis.

Statistical analysis. Data analysis for all aesthetic parameters was first conducted using multivariate analysis of variance (MANOVA) in the general linear models procedure of Statistica 7.0 (Statsoft, Tulsa, OK). The fertility and pesticide program served as the independent variable, and the aesthetic measures served as the dependent variables. When statistically significant differences were detected for any time interval within a given set of aesthetic measurements (quality, greenness, or weed cover), a multivariate repeated-measures approach was employed to examine and compare temporal patterns. Univariate outputs from the repeatedmeasures analysis were examined to determine when differences between programs were statistically significant and between-program comparisons were made using Tukey's honestly significant difference test. We chose Tukey's test because it is slightly more conservative than Fisher's least significant difference test and therefore reduces the chance of making a type I error, which was a major concern given the relatively high amount of variability observed in the field plots. No statistical analysis was performed on the economic data generated.

\section{Results and discussion}

ENVIRONMENTAL CONDITIONS. Patterns of precipitation, measured as rainfall, air temperature, and soil temperature varied across the 2 years of the study (Fig. 1). Rainfall totaled 561 and $669 \mathrm{~mm}$ per year for 2005 and 2006, respectively. Rainfall was slightly higher during Spring 2005 (April-June; $119 \mathrm{~mm}$ ) compared with $2006(111 \mathrm{~mm})$, but precipitation during both years was lower than the 30 -year average $(309 \mathrm{~mm})$ for this period. Precipitation was lower during Summer 2005 (July-September; $305 \mathrm{~mm}$ ) than Summer 2006 (338 $\mathrm{mm}$ ), but summer precipitation during both years was greater than the 30 year average $(271.78 \mathrm{~mm})$. Average air temperatures were slightly higher in $2005\left(22.4{ }^{\circ} \mathrm{C}\right)$ than in 2006 $\left(21.1^{\circ} \mathrm{C}\right)$, with the 30 -year average air temperature being $21.2^{\circ} \mathrm{C}$. Average air temperatures during spring were slightly higher in $2006\left(14.7^{\circ} \mathrm{C}\right)$ than in $2005\left(13.4^{\circ} \mathrm{C}\right)$, with the 30 -year average air temperature for this period being $\left(15.9^{\circ} \mathrm{C}\right)$. Soil temperatures in the summer of 2005 were slightly higher than in 2006, averaging 23.2 and $22.4^{\circ} \mathrm{C}$, respectively. No 30 -year average data for soil temperature were available for this location.

EFFECTS OF FERTILITY AND PESTICIDE PROGRAMS ON TURFGRASS VISUAL QUALITY RATINGs. Turfgrass quality and canopy greenness were only measured during the second study year (2006), which provided a good measure of the short-term effects of these fertility and pesticide programs. Although the NIP resulted in the lowest mean quality ratings when averaged across the season $(P<$ 0.05 ; Table 3 ), visual quality varied significantly over time between fertility and pesticide programs $(\mathrm{F}=8.327$; $\mathrm{df}=30,160 ; P<0.001)$. The NOP resulted in quality ratings that were similar to the IPMP on 6 of 11 rating dates and quality ratings for the NOP were similar to those of the CP on 8 of 11 rating dates. The NOP resulted in significantly higher quality ratings than the NIP on all but three dates and on two of those dates (19 Apr. and 3 May) there were no differences in quality between any of the fertility and pesticide programs.

The IPMP and CP produced their highest turfgrass quality ratings during late summer and fall, with the IPMP producing acceptable quality ratings $(\geq 6)$ on 9 of 11 rating dates, and the CP producing acceptable quality ratings on 7 of 11 dates during 2006. By comparison, the NOP 

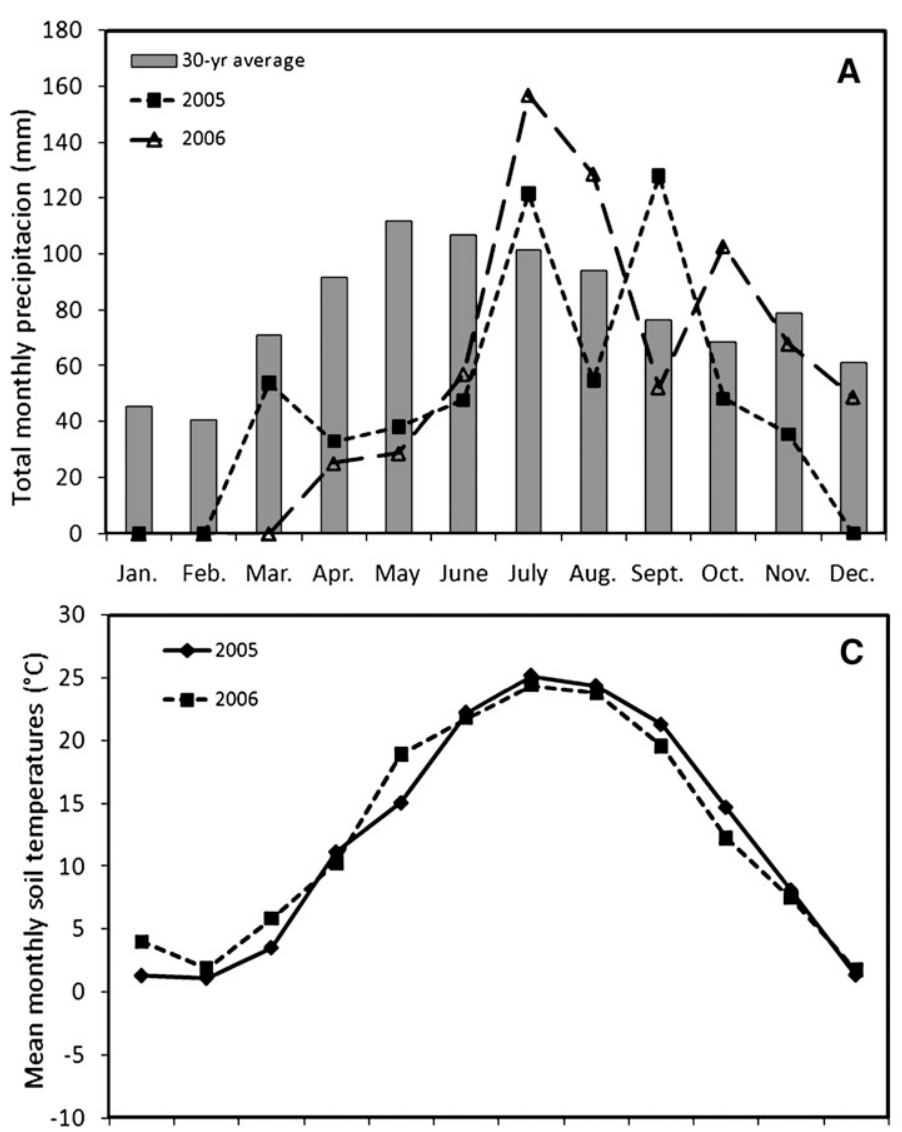

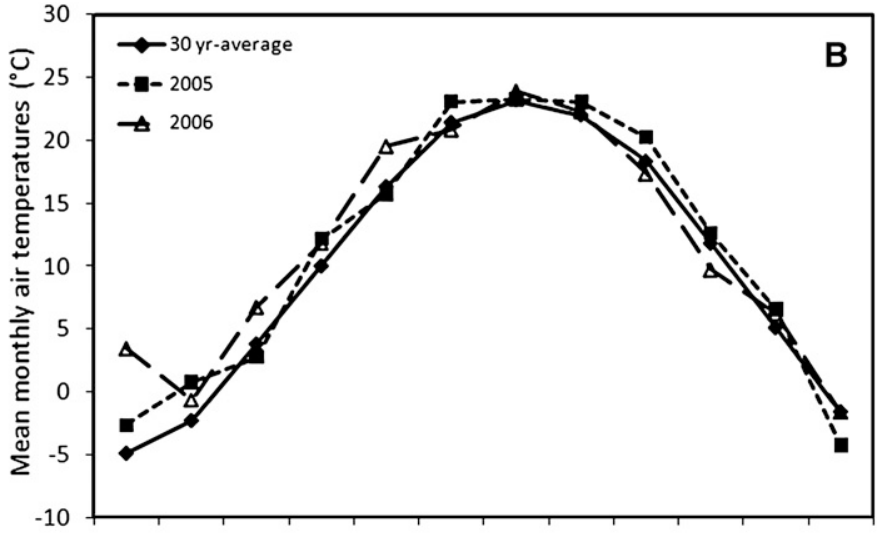

Jan. Feb. Mar. Apr. May June July Aug. Sept. Oct. Nov. Dec.

Jan. Feb. Mar. Apr. May June July Aug. Sept. Oct. Nov. Dec.

Fig. 1. Mean monthly precipitation (Jan. 2005-Dec. 2006) and 30-year precipitation average (1975-2005) (A), mean monthly air temperatures (Jan. 2005-Dec. 2006) and 30-year average temperature (1975-2005) (B), and mean monthly soil temperatures (Jan. 2005-Dec. 2006) [10 cm (3.9 inches) grass cover] (C). Data from Indiana State Climate Office, West Lafayette, IN. Station located 6.1 miles $(9.82 \mathrm{~km})$ northwest of the research plots (lat. $\left.40^{\circ} 28^{\prime} 30^{\prime \prime} \mathrm{N}, \mathrm{long}^{\circ} \mathbf{8 6}^{\circ} 59^{\prime} 31^{\prime \prime} \mathrm{W}\right)$; $1 \mathrm{~mm}=0.0394$ inches, $\left(1.8 \times{ }^{\circ} \mathrm{C}\right)+32={ }^{\circ} \mathrm{F}$.

Table 3. Mean turfgrass quality and canopy greenness in 2006 and total 2 -year maintenance costs associated with four different lawn fertility and pesticide programs: consumer program (CP), integrated pest management program (IPMP), natural organic program (NOP), and no input program (NIP).

\begin{tabular}{|c|c|c|c|c|c|}
\hline \multirow{2}{*}{$\begin{array}{l}\text { Fertility and } \\
\text { pesticide } \\
\text { program }\end{array}$} & \multirow{2}{*}{$\begin{array}{l}\text { Turfgrass quality } \\
(1-10 \text { scale })^{\mathrm{z}}\end{array}$} & \multirow{2}{*}{$\begin{array}{c}\text { Canopy } \\
\text { greenness }^{\mathrm{y}}\end{array}$} & \multicolumn{3}{|c|}{ Total cost $(\$ / \text { acre })^{x}$} \\
\hline & & & 2005 & 2006 & Total \\
\hline $\mathrm{CP}$ & $6.3 \pm 0.2 \mathrm{ab}^{\mathrm{w}}$ & $301.2 \pm 18.4 \mathrm{a}$ & 1371.45 & 1371.45 & 2742.90 \\
\hline IPMP & $6.8 \pm 0.3 \mathrm{a}$ & $295.9 \pm 18.9 \mathrm{a}$ & 1107.09 & 882.25 & 1989.34 \\
\hline NOP & $5.5 \pm 0.2 b$ & $300.0 \pm 13.5 \mathrm{a}$ & 2322.32 & 1175.66 & 3497.98 \\
\hline NIP & $3.9 \pm 0.2 \mathrm{c}$ & $253.9 \pm 10.7 b$ & - & & - \\
\hline
\end{tabular}

${ }^{2} 1-10$ rating scale was used where 10 is the highest possible rating and 6 is considered minimum acceptable coolseason lawn.

'Greenness was measured using a hand-held reflection meter (FieldScout CM-1000; Spectrum Technologies, Plainfield, IL) with 10 measurements taken per plot along a $22-\mathrm{ft}(6.7 \mathrm{~m})$ diagonal transect.

× $\$ 1.00 /$ acre $=\$ 2.4711 /$ ha.

wMeans followed by the same letter are not significantly different according to Tukey's honestly significant difference test at $\alpha=0.05$.

produced its highest quality ratings on two dates during the spring ( 3 and 18 May) and one date during the fall (6 Oct.), but these were the only dates when turfgrass quality ratings for the NOP reached acceptable levels $(>6)$. Although the NIP produced its highest turfgrass quality ratings during spring and early summer, quality ratings for the NIP never reached acceptable levels. During the most stressful part of the growing season for cool-season turfgrasses (measures taken from 28 July to 20 Aug.), only the IPMP and CP provided acceptable quality ratings (Fig.
2, A and B), and only on three of four rating dates during that period. During this same period, the NOP resulted in unacceptable quality ratings $(<6)$ (Fig. 2C), although its aesthetic appearance was slightly better than that of the NIP (Fig. 2D). None of the fertility and pesticide programs provided acceptable turfgrass quality ratings on the 14 July sampling date due to high temperatures and lack of rainfall, which caused the turf to turn brown and start to enter dormancy (Fig. 1).

EFFECTS OF FERTILITY AND PESTICIDE PROGRAMS ON TURFGRASS GREENNESS. Because greenness measurements only included turfgrass plants and intentionally excluded weeds, this measure more specifically reflected how the different fertility and pesticide programs impacted turfgrass plant health. Although the NIP resulted in the lowest mean canopy greenness when averaged across the 2006 season $(P<0.05$; 
Table 3), canopy greenness varied over time with fertility and pesticide $\operatorname{program}(\mathrm{F}=10.11 ; \mathrm{df}=30,160 ; P<$ $0.001)$. For the NIP, peak canopy greenness was observed on 3 May, whereas peak canopy greenness for the CP was observed on 28 July. Peak canopy greenness for the IPMP and NOP was observed on 20 Aug. The NOP resulted in canopy greenness levels similar to or significantly greater than those of the IPMP on 10 of 11 sampling dates, and similar to or greater than those of the $\mathrm{CP}$ on 9 of 11 sampling dates. Although programs that included fertility and pesticide inputs (NOP, CP, and IPMP) provided significantly higher mean canopy greenness than the NIP when averaged across the season $(\mathrm{F}=$ 22.49; $\mathrm{df}=1,16 ; P<0.001)$, these programs provided a significantly greener canopy than the NIP on only three (NOP and CP) or four (IPMP) sampling dates during the season.

As has been observed by others (Mangiafico and Guillard, 2006; Walker et al., 2007; Wilkinson and Duff, 1972), variation in greenness trends were likely due in part to differences in the timing of fertilizer applications and the different $\mathrm{N}$ sources used in each program (Table 2). The fertilizers used in the IPMP and $\mathrm{CP}$ reached color index values as high as 405 and 402, respectively. However, even though the highest color index recorded in the NOP was 366, lower than the peak greenness values for the IPMP and CP, greenness values provided by the corn gluten meal were more consistent throughout the season [seasonal mean of $300 \pm 42.7$ (sd) for the NOP compared with $301.2 \pm 58.3$ for the CP and $295.9 \pm$ 66.5 for the IPMP]. Organic fertilizers need to be broken down by soil microorganisms before the $\mathrm{N}$ can become available to the turfgrass plants (Turner and Hummel, 1992). Thus, the slow release of $\mathrm{N}$ from the corn gluten meal (Christians, 1993) likely made it available to the plant over a longer period of time than the more water-soluble inorganic $\mathrm{N}$ available in the synthetic fertilizers (Turner and Hummel, 1992). Still, even though some variation in greenness was observed between fertility and pesticide programs over the course of the season, average greenness did not differ significantly between programs receiving synthetic
(IPMP and CP) versus organic fertilizer.

EFFECTS OF FERTILITY AND PESTICIDE PROGRAMS ON WEED COVER. An assortment of weedy plant species ranging widely in their life history traits and growth habits were present in plots throughout the course of the study (Table 4). However, white clover (Trifolium repens) and dandelion (Taraxacum officinale) constituted the vast majority of weed cover reaching levels as high as $41.4 \pm 12.2 \%$ (white clover) and $42.4 \pm 9.2 \%$ (dandelion) of total cover in the NIP (Table 5). Considering only these two species, weed cover in
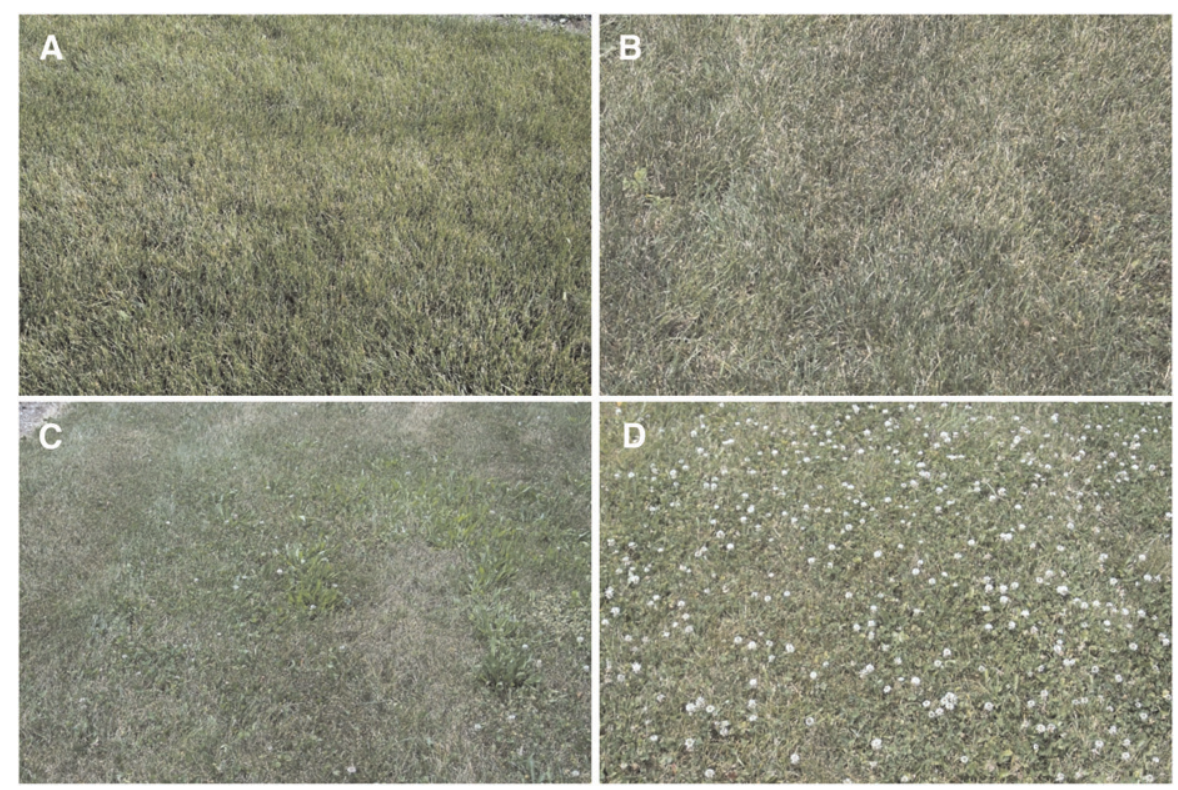

Fig. 2. Influence of four different lawn fertility and pesticide programs on the appearance of turfgrass stands during July 2006: (A) integrated pest management program (IPMP), (B) consumer program (CP), (C) natural organic program (NOP), and (D) no input program (NIP).

Table 4. Weed species detected over the course of 2 years (2005-06) in experimental plots managed using four different fertility and pesticide programs: consumer program (CP), integrated pest management program (IPMP), natural organic program (NOP), and no input program (NIP) in Tippecanoe County, IN.

\begin{tabular}{lll}
\hline Common name & \multicolumn{1}{c}{ Plant species } & Family \\
\hline Sow thistle & Sonchus oleraceus & Asteraceae \\
Dandelion & Taraxacum officinale & Asteraceae \\
Black medic & Medicago lupulina & Fabaceae \\
White clover & Trifolium repens & Fabaceae \\
Ground ivy & Glechoma hederacea & Lamiaceae \\
Yellow woodsorrel & Oxalistricta & Oxalidaceae \\
Buckhorn plantain & Plantago lanceolata & Plantaginaceae \\
Common plantain & Plantago major & Plantaginaceae \\
Large crabgrass & Digitaria sanguinalis & Poaceae \\
Annual bluegrass & Poa annua & Poaceae \\
\hline
\end{tabular}


Table 5. Percentage of cover (rounded to whole digits) by white clover and dandelion in plots managed using four different fertility and pesticide programs: consumer program (CP), integrated pest management program (IPMP), natural organic program (NOP), and no input program (NIP) during 2005 and 2006.

\begin{tabular}{lcccc}
\hline & \multicolumn{4}{c}{ Fertility and pesticide program ${ }^{\mathrm{z}}$} \\
\cline { 2 - 5 } Date & CP & IPMP & NOP & NIP \\
\hline & & White clover cover $[$ mean \pm se (\%)] \\
28 July 2005 & $2.0 \pm 1.5 \mathrm{ab}$ & $0.0 \pm 0.4 \mathrm{~b}$ & $4.0 \pm 2.5 \mathrm{a}$ & $5.0 \pm 1.8 \mathrm{a}$ \\
3 Oct. 2005 & $6.0 \pm 2.0 \mathrm{a}$ & $1.0 \pm 0.5 \mathrm{~b}$ & $8.0 \pm 3.3 \mathrm{a}$ & $10.0 \pm 2.7 \mathrm{a}$ \\
29 Apr. 2006 & $14.0 \pm 6.7 \mathrm{a}$ & $3.0 \pm 3.9 \mathrm{~b}$ & $18.0 \pm 11 \mathrm{a}$ & $32.0 \pm 9.9 \mathrm{a}$ \\
5 July 2006 & $2.0 \pm 3.5 \mathrm{c}$ & $0.0 \pm 0.0 \mathrm{c}$ & $14.0 \pm 7.1 \mathrm{~b}$ & $41.0 \pm 12.2 \mathrm{a}$ \\
6 Oct. 2006 & $0.0 \pm 0.0 \mathrm{~b}$ & $0.0 \pm 0.0 \mathrm{~b}$ & $5.0 \pm 1.7 \mathrm{a}$ & $16.0 \pm 14.7 \mathrm{a}$ \\
& & Dandelion cover $[m e a n \pm s e(\%)]$ & \\
28 July 2005 & $3.0 \pm 1.1 \mathrm{ab}$ & $1.0 \pm 0.8 \mathrm{~b}$ & $3.0 \pm 1.9 \mathrm{ab}$ & $6.0 \pm 3 \mathrm{a}$ \\
3 Oct. 2005 & $7.0 \pm 3.6 \mathrm{a}$ & $5.0 \pm 2.9 \mathrm{a}$ & $8.0 \pm 2.7 \mathrm{a}$ & $11.0 \pm 0.9 \mathrm{a}$ \\
29 Apr. 2006 & $21.0 \pm 4.1 \mathrm{a}$ & $22.0 \pm 6.8 \mathrm{a}$ & $18.0 \pm 10.6 \mathrm{a}$ & $29.0 \pm 8.1 \mathrm{a}$ \\
5 July 2006 & $2.0 \pm 3.2 \mathrm{~b}$ & $0.0 \pm 0.0 \mathrm{~b}$ & $11.0 \pm 9 \mathrm{a}$ & $12.0 \pm 4.2 \mathrm{a}$ \\
6 Oct. 2006 & $10.0 \pm 7.2 \mathrm{ab}$ & $5.0 \pm 4.4 \mathrm{~b}$ & $25.0 \pm 16.7 \mathrm{ab}$ & $42.0 \pm 9.2 \mathrm{a}$ \\
\hline
\end{tabular}

${ }^{\mathrm{z}}$ For each weed species, means within each row followed by the same letter are not statistically different via Tukey's honestly significant difference test at $\alpha=0.05$.

significantly reduced white clover cover compared with the NIP. While the CP resulted in levels of white clover cover similar to the IPMP on one of two sampling dates during 2005 , only the IPMP provided significant reductions in white clover cover compared with NIP. The NOP also resulted in levels of dandelion cover that were similar to levels in the CP and IPMP during both sampling dates in 2005, but only the IPMP significantly reduced dandelion cover compared with the NIP, and only on one sampling date that season.

Again in 2006, cover by white clover and dandelion varied over time between fertility and pesticide programs $(\mathrm{F} \geq 3.56 ; \mathrm{df}=6,32 ; P<0.01)$ with significant between-program variation in white clover cover occurring on all sampling dates, and significant between-program variation in dandelion cover occurring on two of three sampling dates that year. The NOP resulted in levels of white clover cover that were significantly lower than those in the NIP on one of three sampling dates (5 July) (Fig. 2, C and D). Although the CP (Fig. 2B) resulted in levels of white clover cover that were significantly lower than those in the NOP and NIP on two of three sampling dates during 2006, the IPMP program (Fig. 2A) resulted in significantly less white clover cover than the NOP or NIP on all three sampling dates that year. The NOP resulted in levels of dandelion cover that were similar to those in the CP and IPMP on two of three sampling dates during 2006, but dandelion cover in the NOP was not significantly different from the NIP on any sampling date that season. While the CP provided significantly less dandelion cover than the NIP on one sampling date during 2006, the IPMP program provided significantly less dandelion cover than the NIP on two of three sampling dates that season.

The ability of fertilizers and pesticides to positively influence the aesthetic quality of turfgrass lawns has been clearly demonstrated in numerous studies (Alumai et al., 2009; Cheng et al., 2008a; Mangiafico and Guillard, 2006; Walker et al., 2007). Fertilizers contribute to a more vigorous turfgrass stand and can measurably increase turfgrass density and canopy greenness. Herbicide inputs further enhance turfgrass quality by selectively removing broadleaf and grassy weeds, resulting in improved uniformity. In this regard, the higherquality values associated with the IPMP and CP reflect a key weakness of the NOP-the lack of an effective post-emergent herbicide alternative. The pre-emergent herbicidal activity of the corn gluten meal used in the NOP has been previously demonstrated (Bingaman and Christians, 1995; Christians, 1993; Gardner et al., 1997; Liu et al., 1994), and the $\mathrm{N}$ content of this material $(10 \%$ by weight) allows it to double as an organic turfgrass fertilizer in organic turfgrass fertility and pesticide programs. As a result, corn gluten meal could potentially reduce weed cover through a combination of pre-emergent activity, as well as by altering $\mathrm{N}$ availability in the soil. Pre-emergent herbicidal activity would reduce cover by some broadleaf weeds and annual grasses, such as dandelion and large crabgrass (Digitaria sanguinalis), whereas increased soil $\mathrm{N}$ can reduce the competitiveness of white clover (Busey, 2003; Sincik and Acikgoz, 2007). However, its lack of activity against most established weeds resulted in lower turfgrass uniformity, lending to a concomitant reduction in visual quality in NOP compared with the IPMP and CP on some dates.

EFFECTS OF FERTILITY AND PESTICIDE PROGRAMS ON ECONOMIC PARAMETERs. Because the study was not initiated until June 2005, there were fewer fertilizer and pesticide applications during 2005 than in 2006, which was a full season. However, the economic data presented in Table 1 represent estimates for full seasons during both years (2005 and 2006).

For the IPMP, total maintenance costs (materials and labor) were higher in 2005 than in 2006 , primarily due to an application of imidacloprid (Merit 2F) during 2005. Although scouting represented $15 \%$ and $16 \%$ of the total labor in the IPMP in 2005 and 2006, respectively, results indicate that it could also result in substantial economic savings over the long term. Although necessary in 2005 , white grub populations were below treatment threshold levels in 2006, making the application of imidacloprid unnecessary. Therefore, scouting for white grubs resulted in a $54 \%$ reduction in the cost of the IPMP in 2005. Additionally, labor required to apply liquid insecticides and herbicides in the IPMP were relatively low compared with those required to apply the granular products in other programs (Table 1).

Total maintenance cost for the $\mathrm{CP}$ remained the same over the 2 years of the study because scouting was not incorporated as part of this calendardriven program. Consequently, insect control products [bifenthrin (Talstar; FMC, Philadelphia, PA) and imidacloprid] were applied in both years even if they were not necessary. This fact 
represents an important disadvantage of calendar-driven consumer programs when compared with fertility and pesticide programs incorporating scouting. However, incorporation of scouting into the $\mathrm{CP}$ as a decisionmaking tool could have reduced the cost of this program by $\$ 157.6 /$ acre in 2006 if insecticide was not required.

For the NOP, total cost (materials and labor) varied between the 2 years of the study. While scouting represented $10 \%$ and $19 \%$ of the total labor for the NOP in 2005 and 2006, respectively, it provided a $53 \%$ total cost reduction for the NOP in 2006. The reduced costs associated with the NOP during 2006 mainly reflected the costs associated with the application of entomopathogenic nematodes. Entomopathogenic nematodes were considerably more expensive than the synthetic insecticides used in the IPMP and CP. However, because scouting revealed that white grub populations were below treatment threshold levels during 2006, nematodes were not applied. The reduced costs associated with the NOP in 2006 placed it more in line with the IPMP and CP. However, results also indicate that when white grub populations are above treatment thresholds, the NOP may cost twice as much as the IPMP and as much as $70 \%$ more than the $\mathrm{CP}$ (Table 1).

Aside from the NIP, the lowest total maintenance costs were associated with the IPMP program during both years of the study. Even though labor required by the IPMP was higher than the CP in 2005 and higher than the CP and NOP in 2006 , the relatively inexpensive materials used in the IPMP allowed it to remain the least expensive program (Table 1). The fertilizer used in the IPMP had higher $\mathrm{N}$ content than the ones used in the CP and the NOP ( $34 \%$ vs. $28 \%$ and $10 \%$, respectively). This resulted in less fertilizer required per acre to fulfill the $\mathrm{N}$ requirements of the turfgrass. Additionally, insecticides and herbicides applied in the IPMP were less expensive than those applied in the CP (mixed with fertilizer) and the NOP (products needing calibration and careful storage and handling).

Even though there could potentially be some economic differences between fertility and pesticide programs associated with mowing costs, in this study, all plots were equally mowed independent of turf growth response for each individual program. Therefore, the potential difference in cost associated with mowing could not be calculated. However, results of this study clarify how other factors, such as the judicious use of fertilizers and pest control products, could ultimately be an incentive for incorporating alternative management tactics, especially white grub scouting. With recent increases in fertilizer costs due to higher transportation costs, the devaluation of the U.S. dollar, and the commercial release of generic imidacloprid, the IPMP represents a potentially effective option to reduce lawn maintenance costs. Programs incorporating slow-releasing, long-lasting fertilizer sources would also be more economically attractive to homeowners.

\section{Conclusion}

Results of this study aid in developing a baseline for comparing common but disparate management approaches and help to construct a framework for lawn care professionals to evaluate, market, and implement alternative programs that include the use of scouting and organic products. The potential economic benefits of scouting for turfgrass insect pests were clearly demonstrated by the findings of this study, which may help dispel the misconception that scouting is too time consuming and costly to be economically viable. The IPMP produced good results in terms of aesthetics and total maintenance costs, and implementation of a scouting program effectively reduced the overall costs of this program when white grub populations were below treatment thresholds. The CP provided aesthetic results similar to the IPMP, but it was easier to implement than the IPMP or NOP, both of which included scouting. Its ease of implementation stemmed mainly from granular formulations that were easy to handle, and simple application guidelines, including prespecified spreader settings that minimized the calibration process. However, the final cost of the CP was higher than the IPMP. Alumai et al. (2009) also evaluated the economic impact of different turfgrass fertility and pesticide programs and reported that the $\mathrm{CP}$ (managed by a professional lawn care company in their study) and IPMP resulted in higher aesthetic quality ratings than the NOP and NIP. However, the IPMP did so at a relatively lower cost and with fewer inputs compared with the CP. Furthermore, because the CP was based largely on calendar-driven applications of preformulated inputs, there is an increased likelihood that homeowners may be encouraged to make unnecessary applications. The data gathered from this study imply that the incorporation of a scouting regime into the CP may also provide a realistic avenue for reducing the costs associated with calendar-driven applications.

Results also demonstrated the critical need for the development of effective, post-emergent, organic weed controls. The lack of such a product reduced the overall quality of organic lawns mainly because of decreased uniformity resulting from broadleaf weed cover. Although the price of entomopathogenic nematodes caused the NOP to be the most expensive program, like the IPMP, scouting substantially reduced the cost of the NOP when white grub populations were below treatment thresholds, bringing the cost of the NOP more in line with the CP and only slightly more expensive than the IPMP. Dramatic reductions in the quantities of pesticides used and the number of plants treated following the implementation of IPMP in landscape plantings highlighted the unnecessary use of pesticides in traditional pest control programs for ornamental landscapes in a related study (Raupp et al., 1992). Similarly, findings from this study may open the door for more widespread implementation of scouting in turfgrass fertility and pesticide programs. Although homeowners must still decide which management approach best meets their aesthetic and economic expectations, results of the present study help to clarify some of the impacts and potential benefits associated with different management approaches. In particular, these results highlight how incorporation of scouting into different fertility and pesticide programs may provide short-term economic benefits without any significant aesthetic impacts. Results of this study may also provide a basic framework 
for lawn care professionals to evaluate, market, and implement alternative programs that include the use of scouting and organic products.

\section{Literature cited}

Altieri, M.M. and C.I. Nicholls. 2003. Soil fertility management and insect pests: Harmonizing soil and plant health in agroecosystems. Soil Tillage Res. 72:203-211.

Alumai, A.A., S.O. Salminen, D.S. Richmond, J. Cardina, and P.S. Grewal. 2009. Comparative evaluation of aesthetic, biological, and economic effectiveness of different lawn management programs. Urban Ecosyst. 12:127-144.

Beard, J.B. 1973. Turfgrass: Science and culture. Prentice-Hall, Englewood Cliffs, NJ.

Bingaman, B.R. and N.E. Christians. 1995. Greenhouse screening of corn gluten meal as a natural control product for broadleaf and grass weeds. HortScience 30:1256-1259.

Bulluck, L.R. and J.B. Ristaino. 2001. Effect of synthetic and organic soil fertility amendments on southern blight, soil microbial communities, and yield of processing tomatoes. Phytopathology 92:181189.

Busey, P. 2003. Cultural management of weeds in turfgrass: A review. Crop Sci. 43:1899-1911.

Cheng, Z., D.S. Richmond, S.O. Salminen, and P.S. Grewal. 2008a. Ecology of urban lawns under three common management programs. Urban Ecosyst. 11:177-195.

Cheng, Z., P.S. Grewal, B.R. Stinner, K.A. Hurto, and H.B. Hamza. 2008b. Effects of long term turfgrass management practices on soil nematode commu- nity and nutrient pools. Appl. Soil Ecol. 38:174-184.

Christians, N. 1993. The use of a natural product for the control of annual weeds in turf. 11 June 2009. <http://www.hort. iastate.edu/gluten/pdf/cornglut.pdf>.

Desneux, N., A. Decourtye, and J.M. Delpuech. 2007. The sublethal effects of pesticides on beneficial arthropods. Annu. Rev. Entomol. 52:81-106.

Gardner, D.S., N.E. Christians, and B.R. Bingaman. 1997. Pendimethalin and corn gluten meal combinations to control turf weeds. Crop Sci. 37:1875-1877.

Liu, D.L.Y., N.E. Christians, and J.T. Garbutt. 1994. Herbicidal activity of hydrolyzed corn gluten meal on three grass species under controlled environments. J. Plant Growth Regul. 13:221-226.

Mangiafico, S.S. and K. Guillard. 2006. Fall fertilization timing effects on nitrate leaching and turfgrass color and growth. J. Environ. Qual. 35:163-171.

Phelan, P.L., J.F. Mason, and B.R. Stinner. 1995. Soil-fertility management and host preference by European corn borer, Ostrinia nubilalis (Hübner), on Zea mays L.: A comparison of organic and conventional chemical farming. Agr. Ecosyst. Environ. 56:1-8

Potter, D.A. and S.K. Braman. 1991 Ecology and management of turfgrass insects. Annu. Rev. Entomol. 36:383406.

Raupp, M.J., C.S. Koehler, and J.A. Davidson. 1992. Advances in implementing integrated pest management for woody landscape plants. Annu. Rev. Entomol. 37:561-585.

Rebek, E.J., C.S. Sadof, and L.M. Hanks. 2005. Manipulating the abundance of natural enemies in ornamental landscapes with floral resource plants. Biol. Control 33:203-216.

Rochefort, S. 2006. Impact of different types of lawn management on the abundance and diversity of arthropods, and the potential of endophytic grasses to protect plants against herbivore arthropods. Laval University, Quebec City, Canada, PhD diss.

Sincik, M. and E. Acikgoz. 2007. Effects of white clover inclusion on turf characteristics, nitrogen fixation, and nitrogen transfer from white clover to grass species in turf mixtures. Commun. Soil Sci. Plant Anal. 38:1861-1877.

Turgeon, A.J. 2002. Turfgrass management. Prentice Hall, Upper Saddle River, NJ.

Turner, T.R. and N.W. Hummel, Jr. 1992. Nutritional requirements and fertilization, p. 385-439. In: D.V. Waddington, R.N. Carrow, and R.C. Sherman (eds.). Turfgrass. Amer. Soc. Agron., Crop Sci. Soc. Amer., Soil Sci. Soc. Amer., Madison, WI.

U.S. Congress, Office of Technology Assessment. 1995. Biologically based technologies for pest control. OTA-ENV636.

Walker, K.S., C.A. Bigelow, D.R. Smith, G.E.V. Scoyoc, and Z.J. Reicher. 2007. Aboveground responses of cool-season lawn species to nitrogen rates and application timings. Crop Sci. 47:1225-1236.

Wilkinson, J.F. and D.T. Duff. 1972. Effects of fall fertilization on cold resistance, color, and growth of kentucky bluegrass. Agron. J. 64:345-348.

Williamson, R.C. 2007. Modern perspectives in turfgrass insect management. Acta Hort. 762:125-132. 